\title{
Insider Trading Regulation in Japan
}

\section{Citation}

J. Mark Ramseyer, Insider Trading Regulation in Japan, Res. Handbook on Insider Trading 347 (2012).

\section{Published Version}

https://www.e-elgar.com/shop/research-handbook-on-insider-trading? website=uk_warehouse

\section{Permanent link}

http://nrs.harvard.edu/urn-3:HUL.InstRepos:30011623

\section{Terms of Use}

This article was downloaded from Harvard University's DASH repository, and is made available under the terms and conditions applicable to Open Access Policy Articles, as set forth at http:// nrs.harvard.edu/urn-3:HUL.InstRepos:dash.current.terms-of-use\#OAP

\section{Share Your Story}

The Harvard community has made this article openly available.

Please share how this access benefits you. Submit a story.

Accessibility 
ISSN 1936-5349 (print)

ISSN 1936-5357 (online)

\title{
HARVARD
}

JOHN M. OLIN CENTER FOR LAW, ECONOMICS, AND BUSINESS

\author{
INSIDER TRADING REGULATION \\ IN JAPAN
}

J. Mark Ramseyer

Discussion Paper No. 705

$08 / 2011$

Harvard Law School

Cambridge, MA 02138

This paper can be downloaded without charge from:

The Harvard John M. Olin Discussion Paper Series:

http://www.law.harvard.edu/programs/olin_center/

This paper is also a discussion paper of the

John M. Olin Center’s Program on Corporate Governance. 
Forthcoming in Stephen M. Bainbridge, ed., Research Handbook on Insider Trading (Edward Elgar, 2012)

JEL Classifications: K22, G14

J. Mark Ramseyer

Harvard Law School

Cambridge, MA 02138

ramseyer@law.harvard.edu

\section{Insider Trading Regulation in Japan}

\section{By J. Mark Ramseyer*}

Abstract: The U.S.-controlled occupation imposed on Japan in the late 1940s an American-style securities statute. The U.S. statute did not ban insider trading at the time, and neither did the new Japanese law. Not until the 1960s did U.S. prosecutors and judges start to criminalize insider trading. Their Japanese counterparts did not follow their lead, and as of the mid-1980s had left insider trading largely unpoliced.

In 1988, the Japanese Diet banned and criminalized insider trading. Rather than use a vague rule like 10b-5, it carefully specified which investors, which trades, and which contexts would trigger the ban. In 2004, it added an administrative surcharge regime.

Commentators in Japan ostensibly urged the Diet to adopt the bill because they hoped to restore investor confidence in the stock market. If the ban restored investor confidence, it did not show. Shortly after the ban took effect, the Japanese stock market collapsed.

* Mitsubishi Professor of Japanese Legal Studies, Harvard University. I gratefully acknowledge the financial support of the Harvard Law School. 


\section{Insider Trading Regulation in Japan}

\section{J. Mark Ramseyer}

Investors will always bring different amounts of information to the market. They will bring different analytical talents, and different levels of sophistication. Precisely because men and women shrewder and wiser than us buy and sell in the market, we who are more naive can trade at prices that incorporate available information. When Congress passed the federal regulatory framework in the early 1930s, it provided that firms could recover insider profits from a narrow band of investors in a narrow set of trades. But further than that it did not go. Insider trading was not a crime.

That state of affairs was one the Securities \& Exchange Commission (SEC) and the courts would change. Through aggressive prosecution and compliant adjudication, insider trading in the U.S. has become a crime. Citing the general anti-fraud rule, the SEC and the courts now routinely send inside traders to prison.

Occupied by the U.S. for seven years at mid-century, Japan inherited a securities law modeled on the two U.S. statutes. As in the U.S., firms could recover the profits earned by designated insiders in designated trades. Further the law did not go. Insider trading was not a crime.

Many scholars and bureaucrats thought this unfortunate. Without criminal penalties against insider trading, they argued, investors would lack faith in the market. They would avoid stocks and bonds. Because investors would avoid them, so would the firms. Absent criminal penalties against insider trading, Japan could not develop a healthy and robust securities market.

The critics won, and in 1988 the Diet declared insider trading criminal. Investors could now safely "trust the market." And within two years, that market collapsed. Once insider trading became a crime, the volume of shares traded plummeted, and the market capitalization of Japanese firms disappeared. Two decades later, the market has yet to recover.

To tell this story, I first outline the legal context to the Japanese insider-trading ban (Sec. I). I explain the law (Sec. II.A.-B.), and survey its enforcement (Sec. II.C.). I conclude with a short look at the securities market (Sec. III.).

\section{Introduction}

At least since the late 1940s, Japanese corporate law has held directors and officers to a duty of loyalty. Japanese securities law has required them to disgorge their short-swing profits (a Sec. 16(b)-equivalent). ${ }^{1}$ It has contained an anti-fraud rule (a Rule $10 \mathrm{~b}-5$ equivalent). ${ }^{2}$ But for 40 years, Japanese courts saw virtually no litigation over insider trading. They saw no litigation, either civil or criminal, under any of these provisions.

Academic commentators thought this a Bad Thing. At the government advisory committee on securities regulation in 1988, they argued that if insider trading were "allowed to

\footnotetext{
${ }^{1}$ Securities Exchange Act of 1934, as amended, Sec. 16(b).

213 F.R. 8183, Dec. 22, 1948, as amended at 16 F.R. 7928, Aug. 11, 1951.
} 
continue, the health and fairness of the securities market would suffer. The trust of investors in the markets would disappear. To retain that health and trust, the regulation of insider trading was essential." ${ }^{3}$ Along the same line, a standard securities handbook declared that "insider trading blocks the fair development of prices, and erodes the trust of investors in securities markets. Necessarily, it prevents the healthy development of those markets." 4

And so in 1988 the Japanese Diet passed a statute. To facilitate Sec. 16(b)-equivalent claims, it told designated insiders to report their trades to the regulators. It ordered those regulators to scour the reported trades and notify firms of any claims they should raise.

To facilitate criminal prosecutions of insider trading, the Diet passed an additional, entirely new framework. It specified the people subject to its new insider-trading ban. It detailed the firms and trades covered. It listed the information that could be material, and authorized detailed rules about what counted as disclosure.

Draft it and they will sue. Firms still never sue for insider trading under the corporate fiduciary duty provisions. Prosecutors still never file charges under the old Rule 10b-5equivalent. But since 1988, firms have regularly claimed and recovered under the Sec.-16(b)analogue. Prosecutors have regularly charged investors for criminal insider trading under the new statutory sections.

Investor faith and trust in the market? Once the new rules took effect, investors massively pulled their funds. From 1988 to 1990, the number of shares traded on Japanese exchanges fell from 283 billion to 123 billion. By 1992, they fell to 66 billion. In the four years after the Diet banned insider trading, in other words, the number of shares traded fell by an astonishing 77 percent (Figure 1). Perhaps banning insider trading reassures investors about the integrity of the securities markets. But only perhaps. If the Japanese experience suggests anything at all, it suggests exactly the opposite.

[Insert Figure 1 about here.]

\section{Insider Trading Law}

A. Corporate Law:

1. In the U.S. -- Suppose a CEO knows his firm's stock is underpriced. He approaches a shareholder, and offers to buy his stock. Under some traditional (i.e., pre-1934) American case law, he owed a fiduciary duty to that shareholder. If he bought the stock without disclosing what he knew of the underpricing, he violated that duty and owed the shareholder his profit. ${ }^{5}$ Other cases found no such duty to shareholders. ${ }^{6}$ And even those that did describe officers as agents for the shareholders did not necessarily stop them from selling their stock on inside information. After all, the buyer became a shareholder only after he bought the stock. At the time of the purchase, he was not yet a shareholder -- and the CEO owed him no duty. ${ }^{7}$ Absent a fiduciary duty, non-disclosure is not fraudulent: caveat emptor.

${ }^{3}$ Quoted in Wataru Ota, Insaidaa torihiki kisei [The Regulation of Insider Trading] in Yoshiro Miwa, Hideki Kanda \& Noriyuki Yanagawa, eds., Kaisha ho no keizaigaku [The Economics of Corporate Law] 345, 345 (Tokyo: University of Tokyo Press, 1998).

${ }^{4}$ Sin Nihon shoken chosa sentaa, ed., Shoken handobukko (dai 3 ban) [Securities Handbook (3d. ed.) 513 (Tokyo: Toyo keizai shimpo sha, 1989).

\footnotetext{
${ }^{5}$ Hotchkiss v. Fischer, 16 P.2d 531 (Kan. 1932);

${ }^{6}$ Hooker v. Midland Steel Co., 74 N.E. 445 (Ill. 1905).

${ }^{7}$ Joseph v. Farnsworth Radio \& Television Corp., 99 F. Supp. 701 (S.D.N.Y. 1951).
} 
Nonetheless, that a CEO was not the shareholders' fiduciary did not mean he could keep his profits. The question for the courts was not whether he was a fiduciary. He was. It was whether he was a fiduciary to the shareholders, or "only" to the corporation. By standard agency principles, agents may not make "secret profits" on opportunities they acquire through their agency. Instead, they owe their profits to their principal. ${ }^{8}$ If a CEO serves as agent for his firm, then he owes his insider trading profits to it. As the Second Restatement of Agency put it: ${ }^{9}$

[If a director] has "inside" information ...[, then] profits made by him in stock transactions undertaken because of his knowledge are held in constructive trust for the principal. He is also liable for profits made by selling constructive information to third persons, even though the principal is not adversely affected.

And so the U.S. courts sometimes (but not always) held. Officers who traded on information they acquired through their position could find that they owed their profits to the firm. ${ }^{10}$

2. In Japan. -- The Japanese Corporate Code similarly requires fiduciary duties of directors. $^{11}$ It declares a director an agent of the firm (Corporate Code, Sec. 330), and imposes on him a duty of loyalty to it (Sec. 355). ${ }^{12}$ According to the Supreme Court, the duty follows from of the general fiduciary duty that the Civil Code imposes on all agents. ${ }^{13}$ Although the Corporate Code does not explicitly require a fiduciary duty of non-director officers, officers are agents too. By the Supreme Court's logic, they owe fiduciary duties to the firm as well.

Formally, directors and officers would seem to owe the firm any profits they made on inside information. Given that they owe their duties to the firm, however, they apparently do not owe them to the shareholders. If they trade on inside information, they thus would not (absent more) owe those shareholders their profits. Instead, by the logic of the Second Restatement, they would owe those profits to the firm.

Some commentators do imply that directors should pay their insider profits to their firm. "Where a fiduciary transacts with a third party for himself," writes Michio Hamada, professor of law at Nagoya University, he should be "deemed to have engaged in the transaction for the benefit of his principal." ${ }^{14}$ When he sells, he "acquires the proceeds for the sake of his beneficiary. As a result, that beneficiary can demand that he transfer those proceeds to it."

It has been a route the courts did not take. I found no corporate law cases that held insiders liable to the firm on their trades. Neither did I find any commentary that claimed that courts actually did so. Instead, Hideki Kanda, professor of law at the University of Tokyo, explains that such an approach would not fit well with the language of the Code. ${ }^{15}$ Elsewhere (Sec. 423; Sec. 266 of the pre-2004 Commercial Code), the Corporate Code specifies the scope

${ }^{8}$ Reading v. Regem, [1948] 2 K.B. 268 (1948); Tarnowsky v. Resop, 51 N.W.2d 801 (Minn. 1952).

${ }^{9}$ Restatement (2d) of Agency, § 389 Comment c.

${ }^{10}$ Diamond v. Oreamuno, 248 N.E.2d 910 (1969).

${ }^{11}$ Kaisha ho [Corporate Code], Law No. 86 of July 26, 2005.

${ }^{12}$ Prior to 2005, Sec. 254 of Shoho [Commercial Code], Law No. 48 of Mar. 9, 1899, declared the director an agent of the firm. Sec. 254-3 expressly imposed a duty of loyalty.

${ }^{13}$ Arita v. Kojima, 596 Hanrei jiho (S. Ct. June 24, 1970); see Minpo [Civil Code], Law No. 89 of April 27, 1896, Secs. 644-646.

${ }^{14}$ Michio Hamada, Shoho [Commercial Code] 139 (Tokyo: Iwanami shoten, 2001).

${ }^{15}$ Hideki Kanda, Kaisha ho [Corporate Law] 204-05 (Tokyo: Kobundo, 11th ed. 2009). 
of a director's liability to the firm in elaborate detail. Should he cause it to pay too large a dividend, he is liable for the excess. Should he waste corporate assets, he is liable for the loss. In a variety of situations, the statute details what he owes. By the usual implication, if it does not detail something, he does not owe it. As the statute does not tell him to pay the firm his insider profits, he does not owe them.

\section{B. Securities Law:}

1. In the U.S. -- At the time that the lawyers in the American-dominated occupation rewrote Japanese corporate and securities law in the late 1940s, U.S. regulators expected courts to police insider trading through Sec. 16(b) of the 1934 Securities Exchange Act. ${ }^{16}$ If an officer, director, or dominant (over 10-percent) shareholder made money buying and selling his firm's stock within a six-month period, the corporation could sue him for his gains (the section imposes no criminal sanctions). If he refused to pay and blocked the suit, a shareholder could sue derivatively to enforce its right. To let investors learn about the insiders' profits, Sec. 16(a) required officers, directors, and dominant shareholders regularly to disclose their trades.

Although U.S. firms still recover profits under Sec. 16(b), the provision no longer lies at the core of insider trading jurisprudence. Instead, Sec. 10(b) of the 1934 Act has taken its place. ${ }^{17}$ For the last four decades, American regulators and courts have policed insider trading through the anti-fraud provisions of Sec. 10(b)'s Rule 10b-5: ${ }^{18}$

It shall be unlawful for any person ...

a. To employ any device, scheme, or artifice to defraud,

b. To make any untrue statement of a material fact or to omit to state a material fact necessary in order to make the statements made ... not misleading, or

c. To engage in any act, practice, or course of business which operates ... as a fraud or deceit ...,

in connection with the purchase or sale of any security.

For the violators, criminal penalties apply. Sometimes courts impose civil sanctions as well.

Rule 10b-5 says nothing about insider trading, of course. As eventually articulated by the Supreme Court, the rule (sort of) applies anyway because: (i) the rule bans fraud in connection with the purchase or sale of securities; (ii) non-disclosure is fraudulent when a trader owes a fiduciary duty to his counter-party; and (iii) officers and directors owe that fiduciary duty to their shareholders. Table those court opinions that declare that directors and officers owe this fiduciary duty only to the firm itself. Table too the fact that an insider who sells his stock may trade with someone who is not yet (at the moment of purchase) a shareholder at all. Invoke propositions (i) through (iii) anyway, and the courts can (sort of) plausibly declare insider trading (by officers and directors) a violation of Rule 10b-5.

The SEC adopted Rule 10b-5 in 1942, but it did not adopt it to ban insider trading. It began applying it to insider trading only in the early 1960s. William Cary (of "race for the bottom" fame) taught corporate law at Columbia, but from 1961 to 1964 chaired the SEC. In the

\footnotetext{
${ }^{16}$ Securities Exchange Act of 1934, as amended, 15 U.S.C. Sec. 78a et seq.

${ }^{17}$ Securities Exchange Act of 1934, as amended, Sec. 10(b).

${ }^{18} 13$ F.R. 8183, Dec. 22, 1948, as amended at 16 F.R. 7928, Aug. 11, 1951,
} 
Commission's internal, uncontested consent opinion to In re Cady Roberts, ${ }^{19}$ he announced that an investor who traded on nonpublic information violated Rule $10 \mathrm{~b}-5:^{20}$

An affirmative duty to disclose material information has been traditionally imposed on corporate "insiders," particularly officers, directors, or controlling stockholders. We, and the courts have consistently held that insiders must disclose material facts which are known to them by virtue of their position but which are not known to persons with whom they deal and which, if known, would affect their investment judgment.

As Cary well knew, the statement was preposterous legal history. The SEC had taken no such position. Neither had the courts. Cary was trying to move the SEC into an entirely new field, and praying the courts would follow. They did. The Second Circuit adopted this logic in 1969 in Texas Gulf Sulphur, ${ }^{21}$ and the modern 10b-5-based insider-trading jurisprudence began.

Some observers never reconciled themselves to the change, of course. Justice Powell was one. "The SEC," he insisted, "should have gone to Congress long ago" instead of inventing "expansive rules" that pushed the "vague language" of $\S 10(\mathrm{~b})$ "to the edge of rationality." ${ }^{22} \mathrm{He}$ fought a losing cause. The lower courts went with Cary rather than Powell, and by 1980s the use of $10 \mathrm{~b}-5$ as an insider-trading ban had become the norm.

2. Section 16(b) in Japan. -- The U.S.-imposed Securities \& Exchange Act (SEA) ${ }^{23}$ of 1948 blended the 1933 and 1934 U.S. securities statutes. In its Sec. 189, the SEA included a Sec.-16(b)-equivalent. It had started with a Sec.-16(a)-equivalent too, but the Diet repealed it in 1953. ${ }^{24}$ Given that the repealed section had mandated the disclosure of the trades covered by the 16(b)-equivalent, its repeal left shareholders with no way to learn about insider trades. Predictably, they abandoned Sec. 189. As of 1983, University of Tokyo securities law professor Makoto Yazawa could report only one Sec. 189 claim in over thirty years. ${ }^{25}$

All this changed with the massive insider-trading initiative of $1988 .^{26}$ That year, the Diet reintroduced a Sec.-16(a)-analogue in Sec. 188. ${ }^{27}$ In its eventual form, officers and principal shareholders (over 10 percent) reported their trades to the Financial Services Agency. If the Agency decided that an insider owed profits to the firm, it ordered him to pay. If he refused, it

${ }^{19}$ In re Cady, Roberts \& Co., 40 S.E.C. 907 (1961).

${ }^{20}$ In re Cady, Roberts, 40 S.E.C. at 911.

${ }^{21}$ Securities \& Exchange Commission v. Texas Gulf Sulphur Co., 401 F.2d 833 (2d Cir.), cert den'd sub nom. Coates v. S.E.C., 394 U.S. 976 (1969).

${ }^{22}$ Quoted at Kurt A. Hohenstein, Fair to All People: The SEC and the Regulation of Insider Trading, at Virtual Museum \& Archive of the History of Financial Regulation, www.sechistorical.org/museum/galleries/it.

${ }^{23}$ Shoken torihiki ho [Securities Exchange Act], Law. No. 25 of 1948.

${ }^{24}$ Louis Loss, Makoto Yazawa \& Barbara Ann Banoff, Japanese Securities Regulation 194 (Tokyo: University of Tokyo Press, 1983); Hideki Kanda, supervising ed., Chukai Shoken torihiki ho [Annotated Securities Exchange Act] 1173 (Tokyo: Yuhikaku, 1997).

${ }^{25}$ L. Loss, et al., supra note, at 194.

${ }^{26}$ Law No. 75 of 1988.

${ }^{27}$ See H. Kanda, Chukai, at 1173 . The provision would eventually become Sec. 163 of the Financial Products Transaction Act (FPTA). 
notified the company. If within 30 days the company failed to demand the money from him, it reported the trades to the public. ${ }^{28}$

The current Sec.-16(b)-equivalent appears in Sec. 164 of the Financial Products Trading Act (FPTA; the renamed SEA): ${ }^{29}$

For the purpose of preventing the unfair use of secrets obtained by an officer or principal shareholder of a listed company by reason of his office or status, any profit realized by him from any purchase of a specified security of the listed company and sale within a period of six months, or from any sale of of a specified security and purchase within a period of six months, shall be recoverable by the listed company.

With a Sec.-16(a)-analogue available, firms and shareholders have filed claims. Some appear in the press -- e.g., a 2008 claim against the U.S.-based activist fund Steel Partners. ${ }^{30}$ Others appear among reported judicial opinions. Courts uphold the provision against constitutional challenges (violation of property rights). Consistently, they take a prophylactic approach similar to that in the U.S. Firms need not show any damages, for example, and need not show that the defendant had access to any inside information. ${ }^{31}$

3. Rule 10b-5 in Japan. The Americans also imposed on Japan a Rule-10b-5-equivalent. The provision currently appears in Sec. 157 of the FPTA (formerly SEA, Sec. 58):

No person shall engage in any of the following acts:

(a) Employ any unfair device, scheme, or artifice in connection with the purchase or sale (or other transaction or derivative transaction) of a security.

(b) Use any document (or make any statement) containing a fraudulent statement of a material fact or omitting to state a material fact necessary in order to make the statement made not misleading, in connection with the purchase or sale (or other transaction or derivative transaction) of a security, in order to acquire money or other property.

(c) Employ a fraudulent market with the intent of inducing a purchase or sale (or other transaction or derivative transaction) of a security. Violations give rise to criminal penalties.

${ }^{28}$ In its current form, FPTA, Secs. 163, 164(4), 164(7); Hiroyuki Ishizuka, Kin'yu shohin torihiki ho Q\&A 100 [Financial Products Trading Act, Q\&A 100] 200-203 (Tokyo: Nihon keizai shimbun sha, 2006); H. Kanda, Chukai, supra note, at 1173; Yu Kimeda, supervising ed., Insaidaa torihiki kisei no jitsumu [The Regulatory Practice of Insider Trading] 449 (Tokyo: Shoji homu, 2010).

${ }^{29}$ FPTA, supra note.

${ }^{30}$ Japan Law Express, July 12, 2008, japanlaw.blog.ocn.ne.jp/japan_law_express/2008/07/post_3726.html; Reuters July 11, 2008, http://jp.reuters.com/article/businessNews/idJPJAPAN-32708220080711. See also claim by Fisuko on Korean investor Cho Bijun: JC-NET, 4/24/10, at n-seikei.jp/2010/04/post-718.html; JASDAQ's instructions to Paint House to assert claim against Lotus: ja.wikipedia.org/wiki/TMC

${ }^{31}$ [No names given], 1777 Hanrei jiho 36 (Sup. Ct. Feb. 13, 2002) (statute is constitutional), aff'g, 56 Sanhan minshu 346 (Tokyo High Ct. Sept. 28, 2000), aff'g, 56 Saihan minshu 340 (Tokyo D. Ct. May 24, 2000); K.K. Bando hoteru v. Yomeishu seizo, K.K., 1428 Hanrei jiho (Tokyo High Ct. May 27, 1992) (no need to show damages or inside information), aff'g, 1428 Hanrei jiho 143 (Yokohama D. Ct. Sept. 24, 1991); [No name given], 1444 Hanrei jiho 139 (Tokyo D. Ct. Oct. 1, 1992); Y.G. Sanwa Entaapuraizu v. Min. of Finance, 764 Hanrei taimuzu 150 (Tokyo D. Ct. Nov. 2, 1990) (Min. Finance determination of liability is not administrative disposition); Nikko, K.K. v. Y.G. Sanwa Entaapuraizu, 857 Kin'yu shoji hanrei 24 (Kobe D. Ct. July 27, 1990). 
Prosecutors and judges have not used the provision to police insider trading. Recall, however, that the SEC did not write Rule 10b-5 in 1942 to police insider trading anyway. It wrote it to ban fraud, and only under Cary's chairmanship in the early 1960s did it sweep insider trading within the ambit of fraud. In effect, Japanese prosecutors and judges stayed with the American SEC's original plan for the rule.

Sec. 157 began as a general anti-fraud provision, and so it has stayed. As of 2010, courts have published only three opinions interpreting it, and none involves insider trading. In 1963, the Tokyo High Court convicted a trader of securities fraud -- but not insider trading. ${ }^{32}$ In two cases from 2000, the Supreme Court affirmed lower court opinions acquitting Nomura Securities directors of Sec. 157 violations in reimbursing a major client for securities losses. ${ }^{33}$ The case law on Sec. 157 has gone no farther. ${ }^{34}$

4. The 1988 amendments. -- (a) Overview. In 1988, Japan passed a series of changes to let regulators police insider trading. ${ }^{35}$ The economy had boomed spectacularly in the 1960s. After an oil-cartel-induced recession in the 1970s, it boomed again. To fund their growth, firms listed their shares on the stock market. In 1970, 1580 firms listed their stock on the Japanese stock exchanges, for a total market capitalization of 16.8 trillion yen. By 1980, 1729 firms listed their shares at a market capitalization of 80.0 trillion, and by 1987, 1912 listed shares worth 345.6 trillion (Figure 2).

[Insert Figure 2 about here.]

Despite this phenomenal market performance, some scholars and bureaucrats still thought the situation unacceptable. Without criminal and civil penalties against insiders, they argued, investors would not trust the stock market. Worried that insiders rigged the game, investors would avoid it. And if investors avoided it then firms would avoid it too. Without heavier sanctions for insider trading, argued scholars and bureaucrats, the Japanese economy could never grow.

To solve this perceived problem, the Diet passed a statute. Under the new regime, if an officer or director bought or sold his firm's stock while holding material non-public information, he faced criminal penalties. If he bought or sold shares in a tender offer target, he faced criminal penalties. And if a tippee with that non-public information bought or sold stock, he faced the penalties too.

The rules detail a formalistic regime. It is much more formal than the Rule 10b-5 criminal (and civil) jurisprudence in the U.S., but less formal than that of Sec. 16(b). It covers a narrower set of trades than Rule 10b-5, and a broader set than Sec. 16(b).

(b) Who is covered? The 1988 rules apply to a discrete group of specified insiders. The list is exclusive: if a trader is not on it, he is not subject to the rules.

32 Japan v. Uchimura, 5 Kakyu saiban keishu 651 (Tokyo High Ct. July 10, 1963).

${ }^{33}$ Ikenaka v. Tabuchi, 1549 Hanrei Jiho 11 (Tokyo High Ct. Sept. 26, 1995), aff'd, 1729 Hanrei jiho 28 (S. Ct. July 7, 2000); Kawai v. Tabuchi, 1064 Kin'yu shoji hanrei 21 (Tokyo High Ct. Jan. 27, 1999), aff'd, 1096 Kin'yu shoji hanrei 9 (S. Ct. July 7, 2000).

${ }^{34}$ Shinsuke Matsumoto, Saishin Insaidaa torihiki kisei [New: Insider Trading Regulation] 12 (Tokyo: Shoji homu, 2006)(no cases applying Sec. 58 to insider trading); Y. Kimeda, supra note, at 3, 7 n.6 (same).

${ }^{35}$ FPTA, Secs. 166, 167; SEA, Secs. 190-2, 190-3. 
(i) Employees. The statute applies to officers, directors, and others who work at the firm. ${ }^{36}$ Note that it bans them from trading only on information they acquire on the job. Suppose a friend tips a fellow employee information over drinks after work. The employee is not liable as an employee. Instead, he is liable only as a tippee. Although he is liable in either case, the distinction matters -- because if he tips someone else, that other person would be liable only if he (the tipper) learned the information as an employee rather than a tippee. As explained below, secondary tippees may safely trade under the 1988 rules. $^{37}$

(ii) Major shareholders. The Japanese Corporate Code gives shareholders with at least a 3-percent stake access to the corporate books. ${ }^{38}$ If a shareholder acquires information through that access, he may not trade on it (FPTA, Sec. 166(a)(2)). If other investors (e.g., creditors) obtain similar access, they may not trade on the information either.

(iii) Legal authorities. People (e.g., regulators) with legal authority over a company may not trade on any information they acquire through their authority (Sec. 166(a)(3)).

(iv) Contract partners. A firm (or person) that obtains information about another firm through its contractual ties or through negotiations over contractual ties may not trade. $^{39}$ The rule may cover attorneys, accountants, and bankers, as all three work for (or with) a firm under contract -- though if they are also agents of the firm, they may fall within the category of "employees" (above) as well. ${ }^{40}$

(v) Former insiders. Anyone subject to the ban will continue to be covered by it for a year after his affiliation with the firm ends (Sec. 166(a)). Rather than ask when an insider's fiduciary duty to the firm stops, the Japanese statute imposes a bright-line 1-year rule.

${ }^{36}$ FPTA, Sec. 166(a)(1)); S. Matsumoto, supra note, at 44-46.

${ }^{37}$ See Y. Kimeda, supra note, at 50.

${ }^{38}$ Kaisha ho, supra note, at Sec. 433; see S. Matsumoto, supra note, at 46-48.

${ }^{39}$ FPTA, supra note, at Sec. 166(a)(4); see, e.g., [No names given], 1845 Hanrei jiho 147 (S. Ct. Dec. 3, 2003). In some respects, this takes a different approach from footnote 22 of Dirks v. Securities \& Exchange Commission, 463 U.S. 646, 662 n. 22 (1983), though it is consistent with later lower court cases like Securities \& Exchange Commission v. Lund, 570 F. Supp. 1397 (C.D. Cal. 1983).

${ }^{40}$ FTPA, Sec. 166(a)(1). Compare S. Matsumoto, supra note, at 50-54, with Y. Kimeda, supra note, at 41, 62-63. In fact, this distinction should not make a difference.

In other words, rather than sweep lawyers and accountants into the ban by calling them "temporary insiders," Dirks, 463 U.S. at 655 n.14, Japanese law covers them in the statute as either contractual partners or agents. 
(vi) Tender offerors. A person who acquires information from his affiliation (whether by employment, stock holdings, legal authority, or contractual ties) to the acquirer in a tender offer may not trade. ${ }^{41}$

(vii) Tippees. If an insider (by any of the definitions above) conveys information to someone else, that tippee may not trade. ${ }^{42}$ The coverage does not turn on whether anyone breached a fiduciary duty by tipping -- all tips are off limits. ${ }^{43}$ It does turn on whether the disclosure was intentional -- if someone merely overhears a thought-to-beconfidential comment, he may freely trade. ${ }^{44}$

Because the ban covers only those who hear from a defined insider, secondary and tertiary tippees may freely trade. Note, however, that someone who works with a primary tippee (e.g., a newspaper editor who employs an investigative reporter who learns inside information) is not a secondary tippee. Instead, he is a co-primary tippee. ${ }^{45}$

(c) What information is material? The 1988 statute also lists information that is material, but this list is not exclusive. Instead, all information that an investor would consider important in deciding whether to buy or sell is material. ${ }^{46}$ Note that an investor violates the statute if he trades while holding material non-public information; he need not have used it in deciding whether to buy or sell. Note too that the statute authorizes the government to specify events that it exempts as de minimus -- and that the Ministry of Finance maintains such an exempt-event list. $^{47}$

Acting through its board of directors (or other mechanism), a firm might decide to do something that would affect an investor's decision to hold its stock. ${ }^{48}$ Alternatively, it might decide not to pursue an option it had earlier announced it would follow. Both can give rise to illegal insider trading. As illustrations, the statute lists such actions as stock issues, capital reductions, stock buy-backs, stock splits, dividend issues, mergers, business sales, business purchases, liquidations, and new products or technologies (Sec. 166(b)(1).

${ }^{41}$ FPTA, Sec. 167. Japan takes an approach analogous, in other words, to Rule 14(e)-3 of the 1934 Act. Rather than worry about "fiduciary duties" or "misappropriation," Chiarella v. United States, 455 U.S. 222 (1980); United States v. O'Hagan, 521 U.S. 642 (1997), it employed a bright-line rule in the statute.

42 FPTA, Sec. 166(c); e.g., [No names given], 244 Shiryo shoji homu 206 (Nagoya D. Ct. May 27, 2004).

43 Dirks, 463 U.S. at 660 (tippee may trade if tip was not fiduciary duty breach).

${ }^{44}$ Y. Kimeda, supra note, at 70-71. Compare this wth SEC v. Switzer, 590 F. Supp. 756 (W.D. Okla. 1984) (tippee may trade on over-heard information because careless conversation may be a duty of care violation, but does not generate a gain to the tipper, and the Dirks rule hinges on a fiduciary duty breach from which the tipper gains).

45 S. Matsumoto, supra note, at 56; Y. Kimeda, supra note, at 69-70.

${ }^{46}$ FPTA, Sec. 166(b)(4); S. Matsumoto, supra note, at 139-44; e.g., [No names given], 1438 Hanrei jiho 151 (Tokyo D. Ct. Sept. 25, 1992).

${ }^{47}$ FPTA, Sec. 166(b); Kaisha kankeisha to no tokutei yuka shoken to no torihiki kisei ni kansuu naikaku furei [Cabinet Order Regarding Regulation of Trades in Specified Securities, Etc., by Corporate Related Parties, Etc.], Min. Finance Order 10 of Feb. 3, 1989.

${ }^{48}$ E.g., [No names given], 1679 Hanrei jiho 11 (S. Ct. June 10, 1999); K.K. MAC asetto manejimento, 1299 Hanrei taimuzu 99 (Tokyo High Ct. Feb. 3, 2009). 
The firm might also encounter new constraints or possibilities. ${ }^{49}$ Again, the events can give rise to illegal insider trading. As illustrations, the statute lists natural disasters, stock sales by major investors, stock purchases by outside investors, and the delisting of the firm's stock (Sec. 166(b)(2)).

A firm may find that its earlier announcements or financial projections were wrong. They may have been overly optimistic. They may have been unduly pessimistic. In either case, the errors will matter to investors, and an insider who trades on them will violate the insider trading ban (Sec. 166(b)(3)).

(d) What firms are covered? Sec. 16(b) in the U.S. applies only to exchange-listed or very large firms; Rule 10b-5 applies to all corporations. The insider-trading ban in Japan sweeps closer to Sec. 16(b) than Rule 10b-5: it applies only to exchange-listed companies. ${ }^{50}$ If a firm lists at least one type of security on an exchange, then the insider-trading ban applies to all of its securities -- including those it does not list. ${ }^{51}$

(e) What information is nonpublic? Although the 1988 statute states that insiders may not trade on information before other investors have had the chance to incorporate it into their decisions, it authorizes the Financial Services Agency (FSA) to issue bright-line rules about the required disclosure (Sec. 166(d)). The Agency has. For example, it specifies that if insiders want to rely on disclosure to the press, they must disclose the information to at least two firms (e.g., newspapers, the public television network NHK) and wait at least twelve hours. ${ }^{52}$

(f) What securities are covered? The 1988 rules cover stocks and bonds, along with derivatives and other options. Bonds are covered only if the inside information affects default risk. $^{53}$ Options are covered at the time of acquisition -- not exercise. Note that options are covered only if bought from a third party -- not if acquired from the firm itself. ${ }^{54}$

(g) What are the penalties? An investor who violates the rules is subject to a trivial fine (up to 5 million yen). He must, however, disgorge to the state all revenues (all proceeds -- not just all profits) from the insider trading. ${ }^{55}$ He also faces a possible prison term of up to five years (FPTA, Sec. 197-2(m)). Corporations are subject to fines of up to 500 million yen (Sec. 207).

${ }^{49}$ E.g., [No names given], 1671 Hanrei jiho 45 (S. Ct. Feb. 16, 1999).

${ }^{50}$ See Secs. 163(a), 166, as interpreted by Shikko rei Sec. 27-2. Although the statute applies to the OTC market as well as the organized exchanges, because JASDAQ has become an exchange the OTC market has effectively disappeared. See S. Matsumoto, supra note, at 39.

${ }^{51}$ Y. Kimeda, supra note, at 19.

${ }^{52}$ Kinyu shohin torihikiho shikko rei Seirei 321 of Sept. 30, 1965, Sec. 30(a). Alternatively, insiders may disclose to the Tokyo Stock Exchange through its Timely Disclosure Network. Id.; see S. Matsumoto, supra note, at 20, 183-91.

${ }^{53}$ Sec. 166(f)(6); Shikkorei, supra note, at Sec. 32-2; Min. Finance Order, supra note, at Sec. 5; see Y. Kimeda, supra note, at 14, 245 n.487; S. Matsumoto, supra note, at 209-10.

${ }^{54}$ FPTA, Sec. 166(f)(2-2); S. Matsumoto, supra note, at 174-82, 195, 204; Y. Kimeda, supra note, at 21.

${ }^{55}$ FPTA, Sec. 198-2; S. Matsumoto, supra note, at 265-66; [No names given], 1139 Hanrei taimuzu 311 (Tokyo D. Ct. May 2, 2003). 
5. The 2004 reforms. -- In 2004, the Diet added to the 1988 criminal provisions an administrative surcharge regime. Quite what problem it saw with the criminal framework is unclear. To convict a defendant, the government had to prove "intent." ${ }^{56}$ But the intent that it needed to show was nothing more than the facts of the trade in question. Those it would have to show in an administrative proceeding anyway. It did not need to show that the defendant knew the law, or that he knew that what he did was illegal. Certainly, it did not need to prove that he intended to defraud. ${ }^{57}$

Commentators argued that criminal prosecutions created too much work for the government. Administrative proceedings would be simpler, they argued. ${ }^{58}$ To be sure, criminal proceedings brought heavier penalties. If convicted, a defendant owed all the proceeds from his trades to the state -- not just a surcharge calculated from his profits. He risked time in prison. He incurred substantial social stigma. Given those higher costs, a rational defendant would invest more resources contesting the charges. Yet if the higher penalties made defendants fight harder, the government could demand lower penalties. It did not need a separate administrative proceeding.

Maybe criminal prosecutions brought other problems. Perhaps the higher burden of proof raised the government's costs. Perhaps some of the (intentionally) rigid procedural rules raised those costs. Perhaps the government could more easily add staff to the Securities Exchange Surveillance Commission (SESC) than to the prosecutors' offices. Or perhaps it found it too hard to convince overworked prosecutors to spend time on victimless financial crimes. ${ }^{59}$

Whatever the logic, the government argued that an administrative option would let it pursue more cases and in 2004 obtained a civil surcharge regime. Suppose someone violates the 1988 insider trading statute (the same FPTA, Secs. 166-167, that carry criminal sanctions). Under the new regime, the government may sue him in an administrative forum for his net profits. $^{60}$

The concept of the surcharge is simple. Take an investor who sells high on inside information. He owes the government the amount he receives, less the lowest stock price over the two weeks after the information's disclosure (FPTA, Sec. 175(a)). If he buys low on undisclosed information, he owes the difference between the price he paid and the highest price over the two weeks after the disclosure.

\section{Enforcement:}

The SESC at the FSA coordinates enforcement activities. As of mid-2011, it employed a staff of about 400, and assigned a quarter to insider trading and securities disclosure. ${ }^{61}$ To

${ }^{56}$ S. Matsumoto, supra note, at 267.

${ }^{57}$ See S. Matsumoto, supra note, at 273; Y. Kimeda, supra note, at 5 (no need to show profit from information, no need to show intent to make money, no need to show use of information); [No names given], 5 Saihan keishu 2354 (S. Ct. Nov. 15, 1951).

${ }^{58}$ S. Matsumoto, supra note, at 274.

${ }^{59}$ Y. Kimeda, supra note, at i (prosecutors focused on cases showing malum in se).

60 If prosecutors demand disgorgement in a criminal charge, the surcharge remedy disappears as superfluous. FPTA, Sec. 185-7, 185-8; see Y. Kimeda, supra note, at 414; S. Matsumoto, supra note, at 273-277.

61 TSE and SESC websites. 
identify the problematic trades, the staff works with the stock exchanges. In 2005, the Tokyo Stock Exchange investigated about 8,000 transactions, issued warnings when it thought it appropriate, and reported problematic trades to the the SESC. ${ }^{62}$ The Commission also takes tips from the general public -- during the year ending mid-June 2009, about 4800 tips. Most of these involved market manipulation, but it did receive about 500 tips on insider trading. ${ }^{63}$

The Commission investigates transactions it considers problematic. In 2005, it surveyed 7,500 trades for possible insider-trading connections, and more closely investigated $500 .{ }^{64}$ The most serious of these it routes to the prosecutors' office. The less egregious it handles through the administrative proceedings.

The result is a modest but regular level of enforcement (Table 1). ${ }^{65}$ In 2006, the government levied an administrative surcharge on 8 insiders for their trading; in 2009, it imposed the surcharge on 38 insiders. In 2004 and 2007, it prosecuted 4 people for criminal insider trading; in 2006, it prosecuted 8.

[Insert Table 1 about here.]

For the most part, the SESC collects only small amounts through the surcharge. In 2009, it took an average of 1.3 million yen (about $\$ 14,000$ ) per case. Of all surcharge actions brought by May of 2009, in 60 percent it collected less than 100,000 yen (about \$1,050). ${ }^{66}$

\section{The Economy}

The Japanese stock market boomed during the 1980s (Figure 2). The market capitalization of Japanese firms grew from 71 trillion yen at the start of 1980 to 611 trillion by the close of 1989. Then, it collapsed. It has yet to recover. Real estate prices plummeted at the same time.

[Insert Figure 2 about here.]

What caused the massive collapse remains a puzzle. Writers often attribute it to a "bubble," but the comment does not much help. If writers mean that in retrospect prices were too high, they merely restate the question. Given what happened, stock prices in 1989 were indeed "too high." The point is "correct." It is also trivial.

Other writers sometimes describe the collapse as a true bubble: informed investors knew that prices were too high, but bought anyway because they hoped to sell before prices fell. Models of "rational bubbles" notwithstanding, this is obviously hard to fit with rational behavior.

\footnotetext{
${ }^{62}$ S. Matsumoto, supra note, at 27-28; TSE and SESC websites.

63 SESC website.

${ }^{64}$ S. Matsumoto, supra note, at 29-30.
}

65 The numbers are surprisingly hard to confrm. Part of the confusion apparently comes from the fact that the number of "warnings" does not equal the number of defendants -- some warnings apply to multiple defendants, while some defendants violate multiple provisions. Part of the confusion comes from the fact that the surcharge is imposed not just on insider trading but on selected other securities violations as well -- from April 2005 to May 2008, the SESC imposed a surcharge on 52 people, but 13 of the 52 involved fraudulent disclosure offenses. And part of the confusion comes from the fact that the prosecutors' office generally discloses only the total number of defendants prosecuted for securities offenses as a whole -- in 2007 the government prosecuted 7 people specifically for insider trading, but 67 people for securities related crimes. See Shoken torihiki to kanshi iinkai, Kin'yu shohin torihiki ho ni okeru kachokin jireishu [Cases Regarding the Surcharge Under the Financial Products Transactions Act] ii (June 2008) (hereinafter Jirei shu, 2008); Homu sho, Hanzai hakusho tab. 1-3-2-7 (Tokyo: Homu sho, 2010).

\footnotetext{
66 Jireishu, 2008, supra note.
} 
It leaves unanswered why rational investors would buy high knowing that price was about to fall, and phrases like "contagion" just restate the question.

Worse, the notion of a true bubble is inconsistent with much of the rest of the story. Japanese developers bought land in the 1980s, and on it built condominia, golf-courses, office buildings. These were decidedly long-term projects: developers do not build office buildings on short-term projections. And they were projects that made financial sense only if prices stayed high long-term. Real investors, using real money, built real skyscrapers -- on the premise that prices would not fall.

Yet asset prices did fall. I do not know why they fell, but I know that the insider trading ban took effect in 1989. The market collapsed the next year and -- 20 years later -- has yet to recover. If insider trading bans help assure investors of the integrity of the market, Japan offers no evidence of the phenomenon. If insider trading bans help insure the growth of the market, Japan provides no evidence of this either.

\section{Conclusions}

The U.S.-controlled Allied occupation imposed on Japan an American-style corporate and securities law. U.S. law did not ban insider trading at the time, and neither did the new Japanese law. Only in the 1960s did U.S. prosecutors and judges start to criminalize insider trading. Their Japanese counterparts did not follow their lead, and as of the mid-1980s had left insider trading largely unpoliced.

In 1988, the Japanese Diet banned and criminalized insider trading. Rather than use a maddeningly imprecise rule like 10b-5, it carefully specified which investors, which trades, and which contexts would trigger the ban. Perhaps it was the kind of statute Justice Powell had in mind when he urged Congress to draft new legislation rather than follow Cary's lead and attack insider trading through the vague anti-fraud provisions of Rule 10b-5.

Commentators in Japan urged the Diet to adopt the legislation because they hoped -- they said -- to restore investor confidence in the stock market. Only with a ban on insider trading would Japan acquire a healthy market. If the ban restored investor confidence, it did not show. Shortly after the ban took effect, the Japanese stock market collapsed. 
Figure 1: Stock Trading Value and Volume (All Japanese Exchanges)

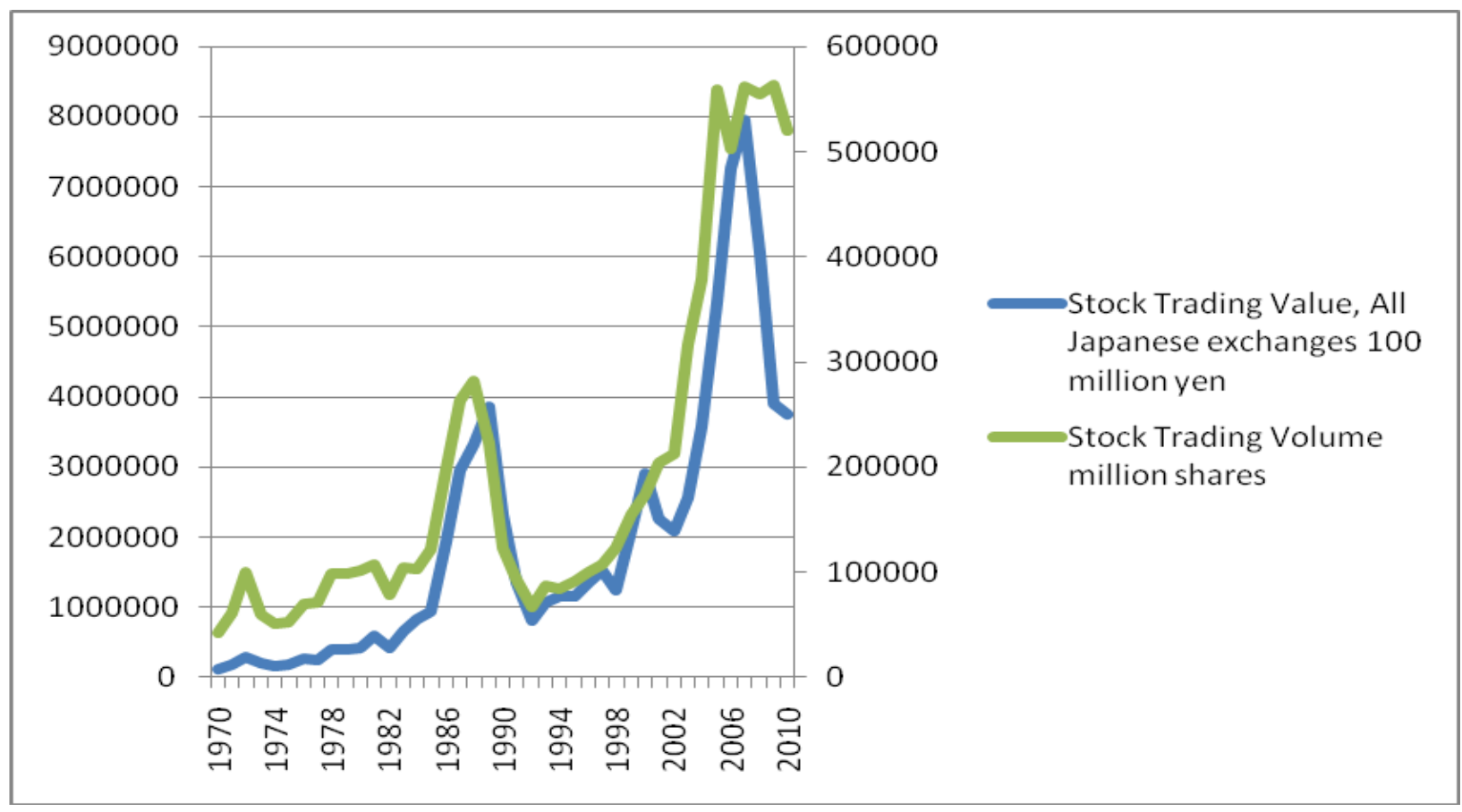

Note: Left axis gives trading value; right axis gives trading volume.

Source: Tokyo Stock Exchange, at http://www.tse.or.jp/market/data/value/index.html. 
Figure 2: Number and Market Value of Listed Companies (All Japanese Exchanges)

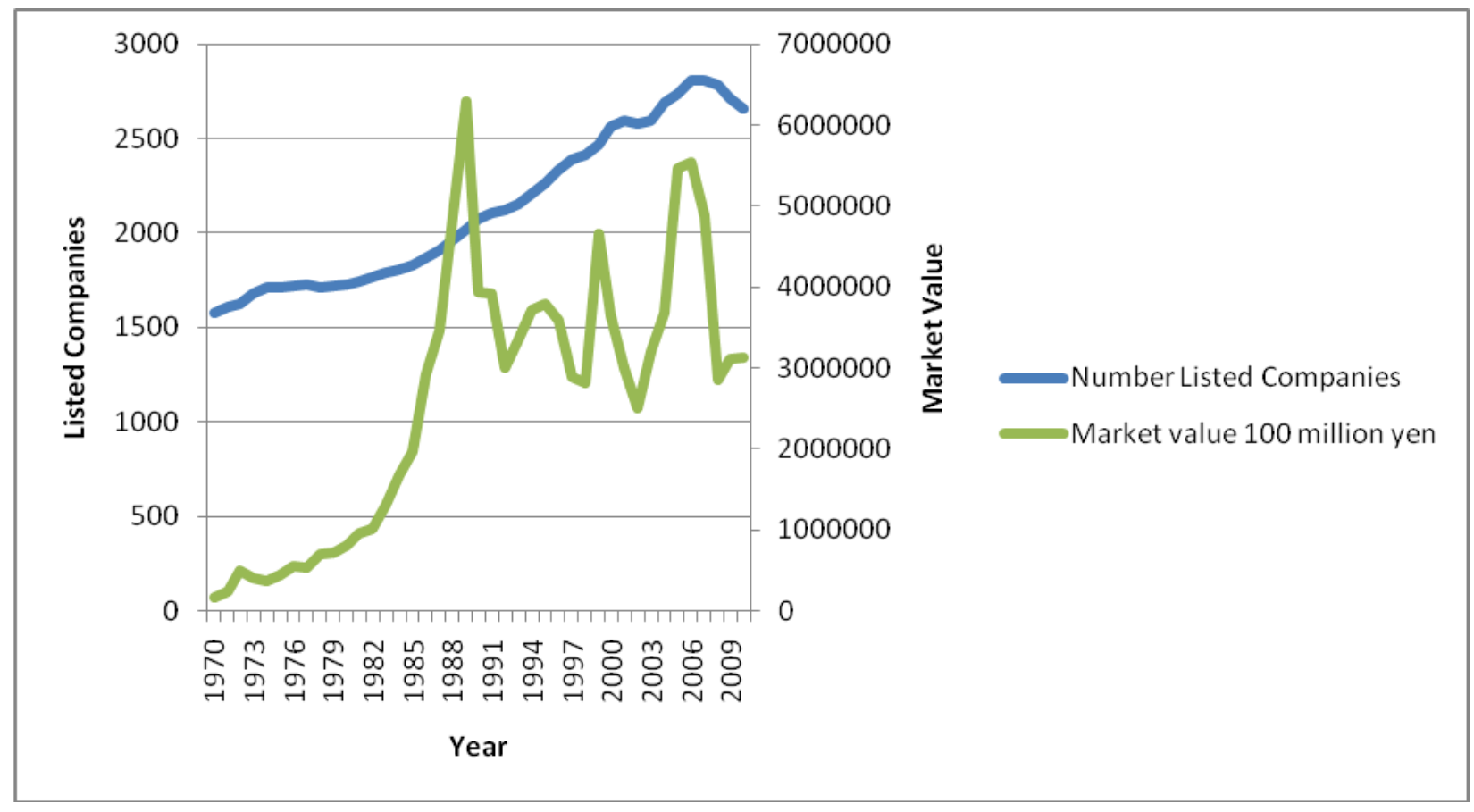

Source: Tokyo Stock Exchange. 
Table 1: Insider Trading Enforcement Levels

A. Administrative Warnings and Surcharge:

\begin{tabular}{|c|c|c|c|c|c|}
\hline & \multicolumn{4}{|c|}{ Defendants } & \multirow{3}{*}{$\begin{array}{c}\text { Per Warning } \\
\text { Surcharge }(/ 1000)\end{array}$} \\
\hline & \multicolumn{2}{|l|}{ Insiders } & \multicolumn{2}{|l|}{ Tippees } & \\
\hline & Non-TO* & TO** & Non-TO & TO & \\
\hline 2006 & 8 & 0 & 0 & 0 & 4,468 \\
\hline 2007 & 9 & 0 & 4 & 3 & 2,475 \\
\hline 2008 & 14 & 1 & 2 & 2 & 3,480 \\
\hline 2009 & 13 & 4 & 12 & 9 & 1,295 \\
\hline
\end{tabular}

B. Criminal Prosecutions:

$\begin{array}{ll}2004 & 4 \\ 2005 & 5 \\ 2006 & 8 \\ 2007 & 4\end{array}$

Note: "Warnings" are "kankoku" for insider trading violations. The columns give the number of defendants. Some defendants were warned on multiple counts, while some warnings applied to multiple defendants.

* Not related to a tender offer. ** Related to a tender offer. Years are from April to March.

Per warning surcharge is the total surcharge collected in the year, divided by the number of administrative warnings imposed.

Sources: Shoken torihiki to kanshi iinkai, Kin'yu shohin torihiki ho ni okeru kachokin jireishu [Cases Regarding the Surcharge Under the Financial Products Transactions Act] (June 2010); Shoken torihiki to kanshi iinkai, Kachokin jireishu no kohyo to insaidaa torihiki jian no keiko ni tsute [Regarding the Publication of Surcharge Cases and the Trends in Insider Trading Cases] (July 2010); Sadakazu Osaki, Tekihatsu ga aitsugu insaidaa torihiki [Disclosure of Insider Trading Continues] (Tokyo: Nomura Research Institute, 2008). 